The

Al] $]$ A $\int \frac{\text { the ASIAN JOURNAL OF ANIMAL SCIENCE }}{\text { Volume } 13 \mid \text { Issue } 1 \mid \text { June, } 2018 \mid 21-26}$

DOI : 10.15740/HAS/TAJAS/13.1/21-26

Visit us | www researchjournal.co in "S

- e ISSN-0976-8963

Volume 13 issue 1 June, $18181-26$

RESEARCH ARTICLE.

\title{
Management practices adopted by goat owners of self-help group under MAVIM in Akola district
}

Jyoti Y. Mote, K. U. Bidwe, R. R. Shelke and S.D. Chavan

Author for Corresponding -

\section{R. R. Shelke}

Department of Animal

Husbandry and Dairy Science,

Dr. Panjabrao Deshmukh Krishi

Vidyapeeth, Akola (M.S.) India

See end of the article for

Coopted authors'
ABSTRACT...... The present investigation on management practices adopted by goat owners of self-help group under MAVIM in Akola district was carried out in Akola district, Department of Animal Husbandry and Dairy Science, Dr. PDKV, Akola during the year 2016-2017. The data of 125 goat keepers belonging to SHG's under MAVIM were collected by personally interviewing with the help of pretested structure. Finally revealed that majority of the goat keepers had knowledge about feeding of leaves of bushes $(100 \%)$, extensive method of rearing $(35.20 \%)$ and type of housing $(40.80 \%)$, goat insurances $(64 \%)$ and duration of feeding of colostrums $(84.80 \%)$. The goat keepers in majority were found to be aware and adopting the practices of buck for natural service (100\%), kaccha or packka type of housing (40.80\%), extensive method of rearing $(35.20 \%)$. The important constraints reported by goat owners were non-availability of pure breeding buck, lack of knowledge about breeding practices, housing requirement, non-availability of grazing area. To overcome the constraints it is proposed to train the goat owners of SHG to develop pasture land at Gram Panchayat level for economic feeding of goats and providing loan facilities to goat owners for purchasing foods and fodders, construction of sheds.

KEY WORDS...... Management practices, Shelf-help group (SHG), Goat, Grazing area, Adopted practices

HOW TO CITE THIS ARTICLE - Mote, Jyoti Y., Bidwe, K.U., Shelke, R.R. and Chavan, S.D. (2018). Management practices adopted by goat owners of self-help group under MAVIM in Akola district. Asian J. Animal Sci., 13(1) : 21-26. DOI : 10.15740/HAS/TAJAS/13.1/21-26. Copyright@2018: HindAgri-Horticultural Society.

ARTICLE CHRONICLE - Received : 28.04.2018; Revised : 17.05.2018; Accepted : 27.05.2018 